\title{
PETROGRAPHIC, PHYSICAL AND MECHANICAL PROPERTIES OF SANDSTONE OF MIRPUR DISTRICT AREA STATE OF AJ\&K, PAKISTAN
}

\author{
Shah Naseer ${ }^{*}$, Didar Ahmad ${ }^{2}$, Zahid Hussain ${ }^{3}$ \\ ${ }^{1}$ Department of Earth Seciences COMSATS University Islamabad, Abbottabad \\ ${ }^{2}$ Department of Environmental Sciences COMSATS University Islamabad, Abbottabad \\ ${ }^{3}$ Department of Geology AJK University Muzaffarabad \\ *Corresponding Author Email: shahnaseer125@gmail.com
}

This is an open access article distributed under the Creative Commons Attribution License, which permits unrestricted use, distribution, and reproduction in any medium, provided the original work is properly cited.

\section{ARTICLE DETAILS}

\section{Article History:}

Received 26 October 2019 Accepted 29 November 2019 Available online 12 December 2019

\section{ABSTRACT}

The project area located in the state of Azad Jammu and Kashmir, Pakistan. It is the northeastern part of Pakistan Geologically the area lies in Kashmir basin. On the southern side, it lies within the extensive Potwar basin. It is an active sedimentary basin. Different Sandstone from different location were collected from the area which is easily accessible and best outcropped with standard size $6 / 6$ inches by helping geological equipment's. After the preparation of the samples, the current study used different type of tests like, (Point load strength Test, Sonic Pulse Velocity Test, Brazilian Test, Uniaxial Compressive Strength Test (UCS), Slake Durability Test and Petrography). Though the microscopic study of the sandstone different minerals and features were identified. The typical mineral assemblage of Mirpur area Sandstone includes Quartz, Tourmaline, Albite. Hornblende, Hematite Plagioclase, Feldspar, Muscovite, Biotite, Cementing martial, Rock fragment, Opaque and Matrix. Geotechnically finding out the ability of water absorption, resistant against weakening, bear and tear, Tensile strength, Compression strength, also find porosity and permeability of Sandstone. Project area underlying the non-marine Neogene fluvial Himalayan molasse deposit sediments.

\section{KEYWORDS}

Geotechnical and Statistical Analysis, Kashmir Basin, Petrographic Analysis, Sandstone, Siwalik Group.

\section{INTRODUCTION}

The Project area encompasses of cover structure of the Indian subcontinantal plate. The Himalayan molasses sediments are uncovered in the area. Molasses deposits are erosional yields of Himalayan thrust omissions and the sediments contemporary in this area, sedimentary source having Sandstone and Clay. These sediments were dumped by the canals of sub Himalayas since the Miocene Himalayan uplift.

The area lies within the Kashmir Basin adjacent to the extensive Potwar region and almost through entire Punjab province. The location of project area in the western limb of the Hazara Kashmir Syntaxis, that is an antiformal arrangement [1]. It contains Sedimentary rock having thickness increases north to south (depressed) and east to west [2]. The sediments were deposit gradually dropping basin under fresh water situation in this basin. Total thickness of the sequence is about 5000 meters and constitutes a major portion of the whole Siwalik group mainly consists of sandstone [3]. Environmental influences and tectonic compressions combinely effect the assets and features of sandstone of the area. Sandstone is a sedimentary rock formed by gradually river deposited, that advance layer by layer over millions of years. It encountered in engineering like tunneling and foundation. It refers to the sand sized ( 0.06 to $2.0 \mathrm{~mm}$ ) clasts cemented by another agent.

Different geotechnical tests were performed and correlation between than to find the properties of sandstone such as bearing capacity, strength and stress of sandstone. These are abrasion resistant properties, but not always strong, usually highly resistant to acid and have rough finish properties. Durability depends upon the binding cemented material and resistance strength. Petrology focuses on detailed descriptions of samples like mineral content and the textural relationships within in detail. The cataloging of sample is based on the data acquired throughout the petrographic analysis. In Petrography Polarizing microscope was used to study thin sections for petrographically and mineralogical investigations for describe the sample pore spaces, micro-texture and structure are critical to understanding [2]. In 1849 English scientist Sir Henry Clifton was prepared first time on a calcareous thin section of rock but he did not record the details of the procedure he used at that time, he did so later in 1868.

Sandsone is used as construction material. The present study is to understanding saltered properties of sandstone such as Petrographic, Physical and Mechanical of Mirpur District area for construction reliability.

Mirpur city located on the Samwal-Jharikass active fault-line, which had several earthquake pasts. Earlier the fault line was triggered during the 2005 earthquake with infrastructure damaged, which may be future risk for infrastructure and construction building.

\section{MATERIAL AND METHODOLOGY}

\subsection{Study Area}

The area lies between the latitude $\mathrm{N} 33^{\circ} 05^{\prime}$ to $33^{\circ} 07^{\prime}$ and $\mathrm{E} 73^{\circ} 37^{\prime}$ to $\mathrm{E}$ $73^{\circ} 45^{\prime}$ in sub-Himalayas Kashmir basin. It is Intermountain Neogene Quaternary characteristics basin. In this area the sediments are asymmetric disposition having distinct NW-SE. Zanskar Mountain and Pir Panjal mountainous Range, bounded the Intermountain Neogene Kashmir basin [4] in the ENE and WSW respectively. Stratigraphically the project area consists Siwalik group because and the floor of basin mainly enclosed by weakly consolidated deposits [4].

\subsection{Sampling Method and Procedure}

The first step towards the investigation starts with knowing everything about it. This was followed by the collection of samples from many well exposure and easy accessibility with the help of different geological equipment's such as Brunton compass, Global Positioning System (GPS), geological hammer, hand lenses, hammer and chisel and sample positions were determined by Global Positioning System (GPS). The mineral grains 
in these samples were identified under the microscope. Two samples of each rock unit were collected from each location after collection, proper name is assigned with different abbreviations i.e. "NKM" is for Nagri Formation Kaladab Mirpur district and "DNM" is for Dhok Pathan Mirpur district also abbreviations written as like (DNM A, DNM B DNM C etc.). Than samples were prepared (core extraction, cutting, grinding) in a rock cutting section and shape of core approximate of $54 \mathrm{~mm}$ diameter and $108 \mathrm{~mm}$ length of core. Four cores from each sample were extracted by drilling machine and perform the tests on each core (Point load strength Test, Sonic Pulse Velocity Test, Brazilian Test, Uniaxial Compressive Strength Test (UCS), Slake Durability Test and Petrography) in Geotechnical laboratory. The specimens in a wet condition immerse them in water for 48 hours at $22+20 \mathrm{C}$ weight the specimen. Than the specimen placed in the dry condition, dry for 48 hours at $60+20 \mathrm{C}$ again weight the specimen. After removing the specimens from the oven, cool them to the room temperature in a desiccator before testing them. A petrographic microscope was then employed to perform a random 300 point-count modal analysis on each thin section. Through petrographic analysis astimates of grain size, grain shape, and degree of sorting were made for all location Sandstones [5]

\subsection{Geology Sitting of Study Area}

The Siwalik Group is geologically, earliest mountain range. It extends eastwest and a mostly southern portion of the Himalayas. In1864 Medlicott named the Siwalik group first time on the basis of vertebrate fossils. The group comprises sandstone and clay dominantly. It's distributed into four lithostratigraphic units having gradational contact [6]. Himalayan rocks are the source of the sediments origin. The Siwalik Group rocks are the result of current Indus River system [7]. Stratigraphic units visible in the area are Late Miocene Nagri Formation, Late Miocene Dhok Pathan Formation, Pliocene Soan Formation [6], Recent alluvium [4] and Mirpur conglomerates having well-rounded to semi-rounded pebbles and boulders of limestone, cherty dolomite, sandstone, quartzite, metamorphic rocks, granite, gneiss and Panjal volcanics (ranges from 5$200 \mathrm{~mm}$ diameter) [8].It exposed in the Hill Khurd area have silty and clayey matrix.

Table 1: The stratigraphic sequence of the project area [8]

\begin{tabular}{|c|c|c|}
\hline Formation & Age & Description \\
\hline Alluvium & Recent & $\begin{array}{l}\text { Unconsolidated deposits of clay, silt and } \\
\text { gravel. }\end{array}$ \\
\hline \multicolumn{3}{|c|}{$\ldots$} \\
\hline $\begin{array}{l}\text { Mirpur } \\
\text { Formation }\end{array}$ & Pleistocene & $\begin{array}{l}\text { Poorly sorted conglomerates consisting of } \\
\text { pebbles, cobbles of sedimentary, } \\
\text { metamorphic, igneous rocks and clay } \\
\text { matrix. }\end{array}$ \\
\hline \multicolumn{3}{|c|}{$\ldots$} \\
\hline $\begin{array}{l}\text { Soan } \\
\text { Formation }\end{array}$ & Pliocene & $\begin{array}{l}\text { Bentonite clays and conglomerates } \\
\text { consisting of fragments of cherty } \\
\text { dolomite, Panjal volcanics, granite } \\
\text { gneisses, basic dikes/sills and quartzite } \\
\text { veins and compact arenaceous matrix. }\end{array}$ \\
\hline $\begin{array}{l}\text { Dhok } \\
\text { Pathan } \\
\text { Formation }\end{array}$ & $\begin{array}{l}\text { Late } \\
\text { Miocene }\end{array}$ & $\begin{array}{l}\text { Grey, fine to medium grained, medium to } \\
\text { thick bedded sandstone with clay and } \\
\text { siltstone. Sandstone } 60 \% \text { and clays } 40 \% \text {. }\end{array}$ \\
\hline $\begin{array}{l}\text { Nagri } \\
\text { Formation }\end{array}$ & $\begin{array}{l}\text { Late } \\
\text { Miocene }\end{array}$ & $\begin{array}{l}\text { Greenish grey to light grey, massive } \\
\text { medium to coarse gained sandstone, } \\
\text { siltstone and mudstone. The sandstone } \\
\text { alternates with clays. The clays are (30- } \\
40 \%) \text { and the sandstone are }(60-70 \% \text {.) }\end{array}$ \\
\hline
\end{tabular}

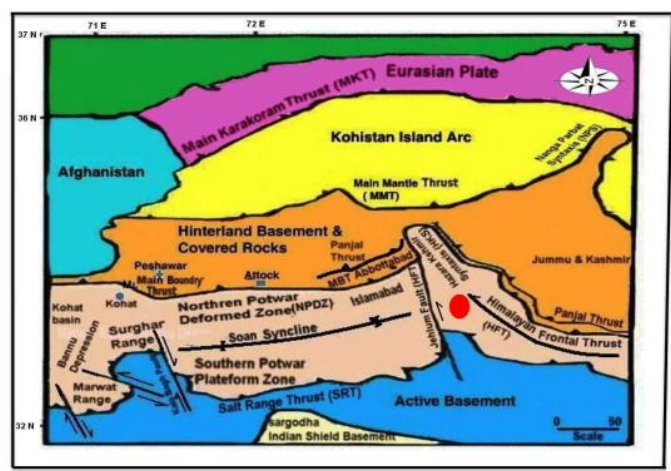

Figure 1: Location map circle showing projects area on regional tectonic Map of NW Himalayan Pakistan after (Baig and Lawrence in 1987)

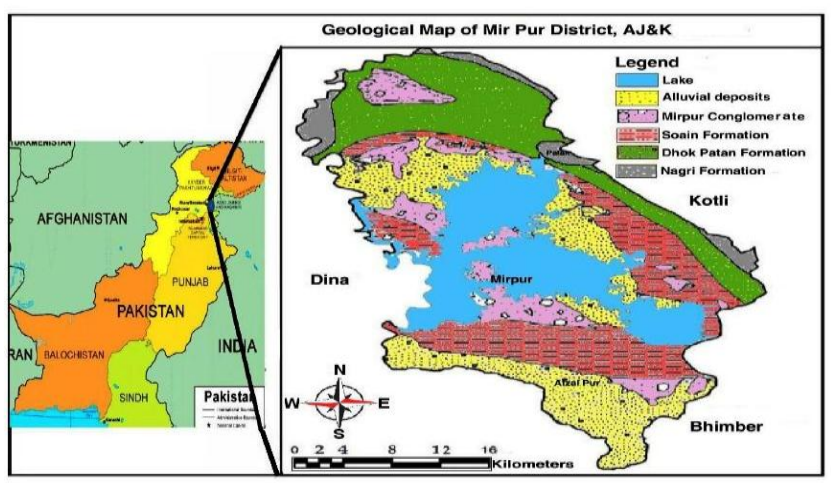

Figure 2: Geological map of Siwalik group, Mirpur District, Kashmir [3]

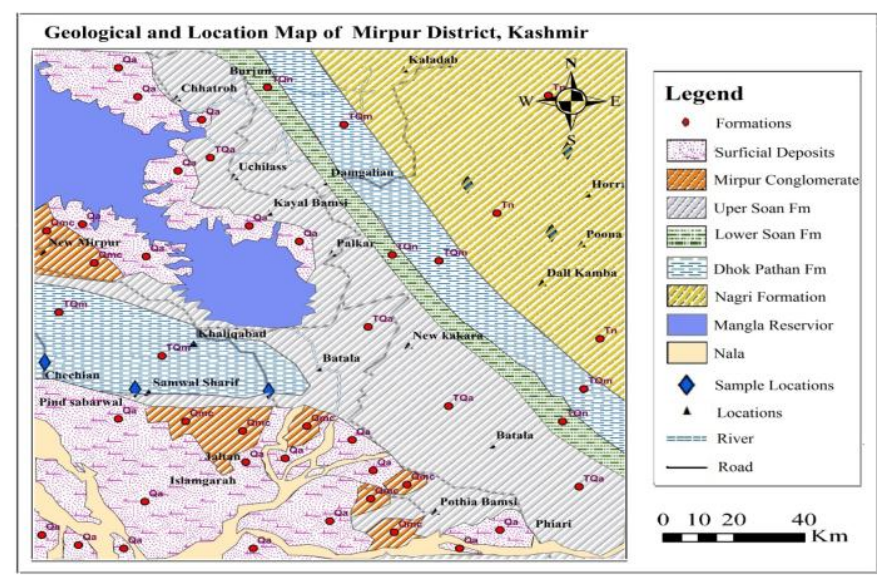

Figure 3: Geological and sample location map of Siwalik group, Mirpur Distric Kashmir. Modified after GSP Topo Sheet No30-F/6 AJK2004

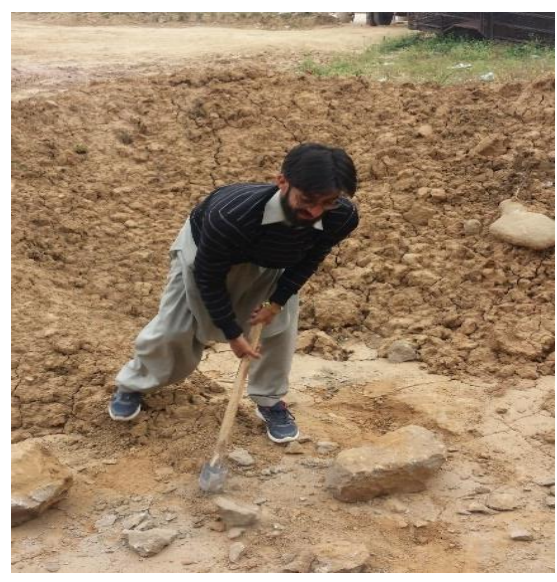

Figure 4: Samples Preparation During Field

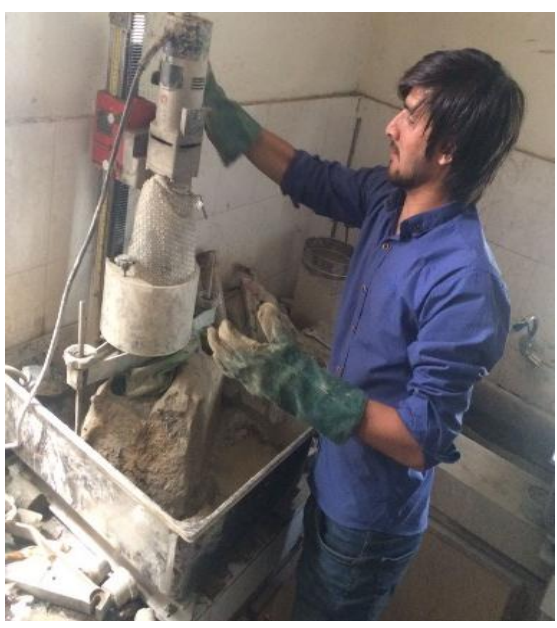

Figure 5: Drill Coring 


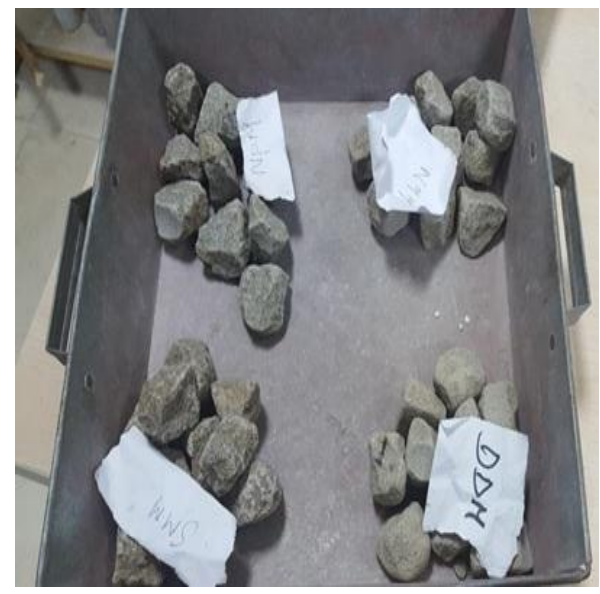

Figure 6: Cored Sample Collection

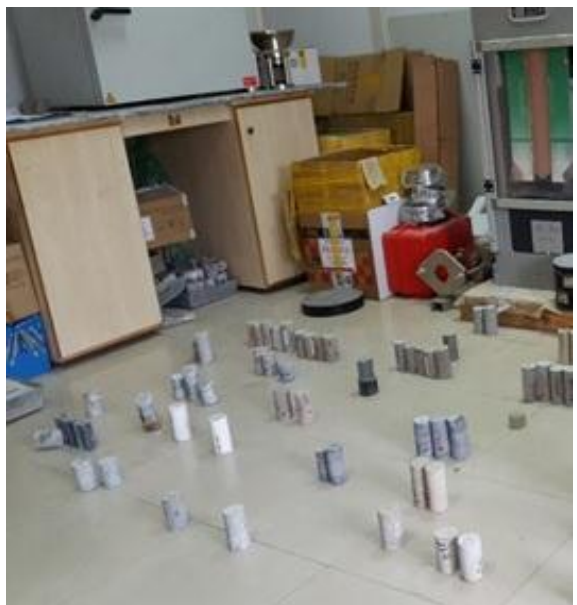

Figure 7: Samples Ready For Slake Durability Test

\section{RESULTS AND DISCUSSION}

\subsection{Petrographic Analysis}

Sandstone of Mirpur District area contains quartz includes highly variable in shape, size, roundness, sphericity and optical properties and show wave or undulatory and point contact varieties of quartz such as monocrystalline and polycrystalline. Feldspar (Albite), Rock Fragments having metamorphic, igneous and sedimentary origin, accessory minerals, including biotite, Muscovite chlorite, hornblende, hematite, tourmaline and opaque minerals. Matrix (sericite, clays) and the cementing material having (calcite, silica etc.). Some rocks have chalcedony cement. Chalcedony cement has "plumose texture". The radiating groups of quartz are visible in chalcedony cement. Commonly, the sandstone consist less than $15 \%$ matrix means the sandstone is arenite type. Quartz grain size is developed by pressure solution during diagnosis of sandstone. Litharenites are enormous, planar to cross bedded, intermediate to coarse grained and are relatively glowing cemented sandstones [9]. Quartz varies from $(25-40 \%)$, rock fragments $(16-40 \%)$, feldspar (4-11\%) and matrix $(1-10 \%)$ [9]. Litharenites are basically clast of igneous, sedimentary and metamorphic rocks. Feldspar grain is fractured and deformed form in litharenites shows alteration to sericite.

The percentage of quartz is Maximum. Polycrystalline quartz grains are basically lithic fragments. Most sandstones are K-feldspar dominates over plagioclase and replaced by cement because it is more extensive. In many rock samples silica commonly overgrowth on quartz. Mainly are abraded [10]. Both forms of feldspar are exchanged by cement replacement of plagioclase feldspar by cement is additional extensive. Silica overgrowth on quartz is collective in many samples. By the polarizing microscopic resulting carbonate and zeolite cement have been recognized [10]. The grains are easily deformed at high temperature. Polycrystalline quartz grains are easily deformed by pressure solution than the monocrystalline quartz. The calcite is the dominant of cement between pore spaces of lit arenites and greywacke during lithification. Formation of calcite cement is favored by a higher concentration of calcium carbonate in the pore water. Apart from calcite, silica also acts as cementing material. The silica content in sandstone increases with decrease in matrix content [11]. Minor amount of chart is precipitated between pore spaces of sandstone. The mafic rock fragments possess porphyritic and coarse chondrite texture. The quinqualoculina in bioclastic, cone in cone structure rhomb and scars as well as the compositional sector zoning form the texture of carbonate rock fragment [12]. An application is illustrated using sandstone data published by Hawkins and McConnel (1991) whereby the possible infuence of petrological characteristics on their geotechnical properties has been assess [13]. Petrographic analysis of project area sandstone is shown in Table 2.

Table 2: The petrographic analysis of the project area

\begin{tabular}{|l|l|}
\hline Minerals & Percentage (\%) \\
\hline Quartz & $28-40 \%$ \\
\hline Cementing martial & $20-35 \%$ \\
\hline Rock fragment & $20-25 \%$ \\
\hline Albite & $3-4 \%$ \\
\hline Muscovite & $2-3 \%$ \\
\hline Tourmaline/ Opaque & $2-3 \%$ \\
\hline Hematite & $2 \%$ \\
\hline Chlorite/ Hornblende & $2-3 \%$ \\
\hline Matrix & $3-5 \%$ \\
\hline Total percentage & $\mathbf{1 0 0} \%$ \\
\hline
\end{tabular}

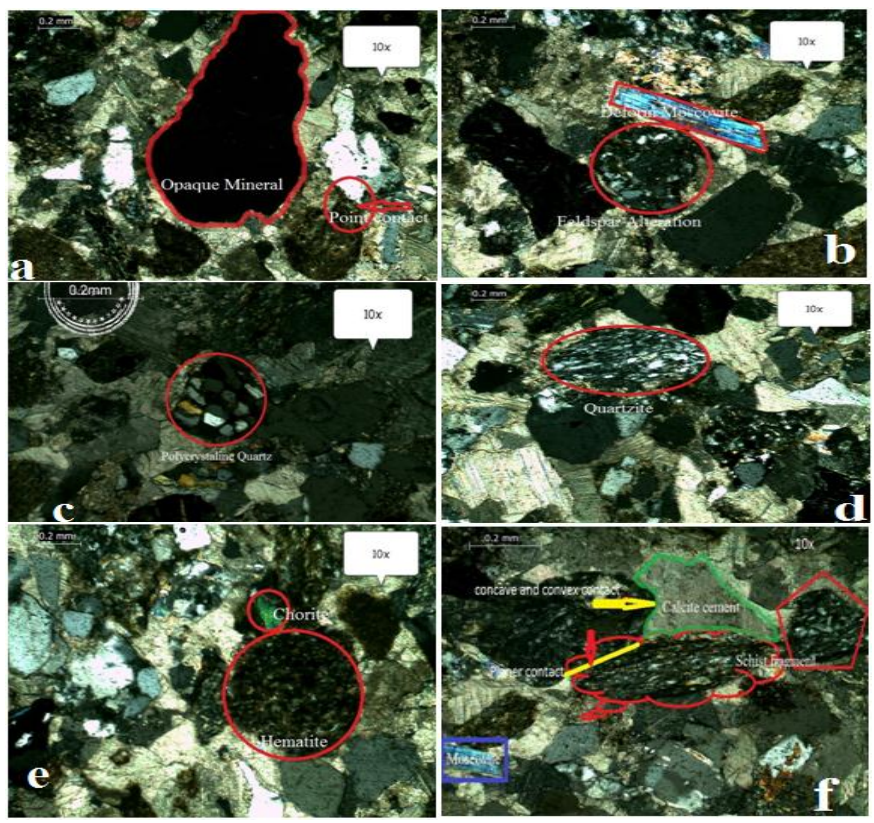

Figure 8: Photomicrograph shows (a) Opaque Minerals and Point Contact, (b) Feldspar alteration and Muscovite, (c) Polycrystalline Quartz, (d) Quartzite, (e) Hematite and Chlorite (f) Calcite Cement, Schist, Albite, Hornblende and Matrix of Mirpur district area sandstone on 10x.

\subsection{Geotechnical Analysis}

Due to orogeny of Himalayan material continuously deposit in Foreland basin. And the under burial sediment changes their chemical and physical properties the sediment particle comes to close and they become compacted. Due to compaction loose and unconsolidated material start lithified pore, spaces become to reduce the cementing behavior particle fill pore spaces. It strongly held grains together finally transform into hard and compact rocks. Compaction is basically caused by a combination of grains, ductile deformation of rock fragments and Quartz dissolution. Compaction of Schists and Muscovite in rock, reinforced, Quartz and cement reduce porosity and permeability. The Authigenic clays are formed feldspar and mica mineral decomposition in sandstone. These are advanced in the sediments presently after deposition or during interment or diagenesis.

Geotechnical properties controlled features having dynamic properties which can change in response to the environment and human intervention [13] such as mineralogy, material and pore water.The effects of sample rock fabric, material and physical environments can be studied with 
different reliable sources for corrections required to test results [14]. At the end discuss the matters related to essential condition and effect of fractures [14]. Study of the spatial distribution of different sediment fractions is resourceful parameters to understand various depositional environments for both earliest and current sediments [15]. The solubility of grain at contact usually increases under stress during a process called pressure solution or chemical compaction. The dissolution of grain under lithotomic stress is an important criterion for the recognition of rock [15]. The grains are easily deformed at high temperature. Quartz have two types one is polycrystalline and the other is monocrystalline. The polycrystalline quartz grains are easily deformed by pressure solution than the monocrystalline quartz. The calcite is the dominant type of cement precipitated between pore spaces of lit arenites and greywacke during lithification [11]. Cement is compaction agent greater amout in pore spaces have greater compaction. Pore spaces are generated by rock degradation. This process is mostly affected by the physical improvement (growth in pore spaces) not by the mechanical development (mineral variation). lit arenites and greywacke dominant sandstone is more resistive than other. The fracturing, dissolutions, stylolitization, clay minerals authigenesis, calcite and silica cementation indicate diagenetic changes in the rocks [12]. Different Geotechnical properties in sandstone would be expected to contain variability and uncertainty of an element. RSE is a method of quantitatively deqning the effect that a particular input (in this case, geological characteristics) might have on a particular output (in this case, Geotechnical properties). Potential RSE (PRSE) and Global Potential RSE (GPRSE) are considered for a data set published by Hawkins and McConnel (1991) concerning the strength of sandstone, based on testing [13].

\subsection{Slake Durability Test}

Slake durability is the Geotechnical property of materials. It closely related to evaluate the weathering resistance depending upon mineralogical composition and resistance measuring of rock sample against weathering and disintegration. The degradation process occurs in all type geological formations. Both intact samples and samples aged by the action of drying wet and freeze-thaw cycles have been tested with the Slake Durability Test (SDT) [16]. As a result, crack and weakening of samples. weakest samples degrade very fast during freeze-thaw cycles they show no linear term. The aging cycles increase the contrast between durable and weak rocks, thus allowing a much better prediction of their future behavior [16].

Slake Durability test perform on 4 samples i.e. is NMM A, NPM A, SMM A and DDM $C$ and result values are maximum strength value is 99 , minimum strength value is 86.34 and average value is 92.67 . The index values of sample NMM A is after the 1st cycle is $97.1 \%$ after the 2 nd cycle it is $95.7 \%$ difference is $1.4 \%$ and index values of sample NPM A after 1 st cycle is $99 \%$ after 2 nd cycle it is $98.2 \%$ their difference is $0.8 \%$.The index values of sample SMM A after the 1st cycle is $97.6 \%$ after the 2 nd cycle it is $96.5 \%$ difference is $1.1 \%$.The index values sample DDM C after the 1st cycle is $91 \%$ after the 2 nd cycle it is $86.34 \%$ and difference is $4.66 \%$.Index value of the NPM A sample was found to be higher than other. Moreover, it could be claimed that the DDM C sample tended to present more disintegration due to layers. The sample test results with respect to Index Day shows in Fig 9.

All confirmed sandstones exposed an intermediate percentage of weightiness loss due to the energy imposed, they were initiate to be sensitive to involvement into water. DDM C sample appearances the greatest water-sensitivity of around $4.66 \%$. The average weight loss of samples is $1.99 \%$. These outcomes are described here in the form of weight loss, compactness bead, reducing the UCS and elasticity of the confirmed sandstones.

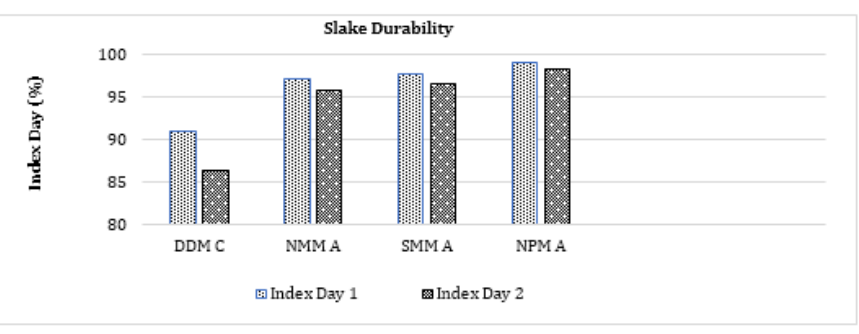

Figure 9: Samples test result with respect to Index Day

\subsection{Uniaxial Compressive Strength Test (UCS)}

The test is performed for evaluating the strength (resistance), deformation (breaking) and stability (load bearing) of samples, engineering structure Compressive strength is the load that a rock can bear before it crushes. In more specific terms it is a measure of the applied stress (load per unit area) at failure. Perform test on different samples collected from the project area. Uniaxial compressive strength (UCS) was conducted on 9 rock samples of sandstone and the result values is the maximum compressive strength value was $88.44 \mathrm{MPa}$ and minimum value was 25.44MPa. The average compressive strength value was 56.94MPa. The stress-strain result of UCS test is shown in Fig 9. Specimens of Sandstone DDM C, DNM C, DDM E, DNM B, SSM C, NPM B, NPM A, NKM A and SSM A failed at 25.47MPa,31.18MPa,35.13MPa, 36.43MPa, 55.42MPa, 56.24MPa $68.39 \mathrm{MPa}, 87.37 \mathrm{MPa}$ and $88.43 \mathrm{MPa}$ respectively. The greater loaded amplitude, the lower the fatigue strength (Inversely proportional).

As can be realized in fig 10, partially weathered rocks contribute greate UCS values associated to definitely weathered rocks. It appears that weathering and saturation performance an significant role in asset reduction. All tested samples have low resistance against the exert load. Normaly the strength of sandstones of research area have not greater and they have intermediate pore spaces and compaction. If pore spaces percentage is less than samples have more compaction and greater strength. The highest value of strength is about $88.43 \mathrm{MPa}$ that is the value of SSM A and lowest value is $25.47 \mathrm{MPa}$ that is DDM E. It means SSM A sample have low pore spaces and greater compaction as compare to DDM E.

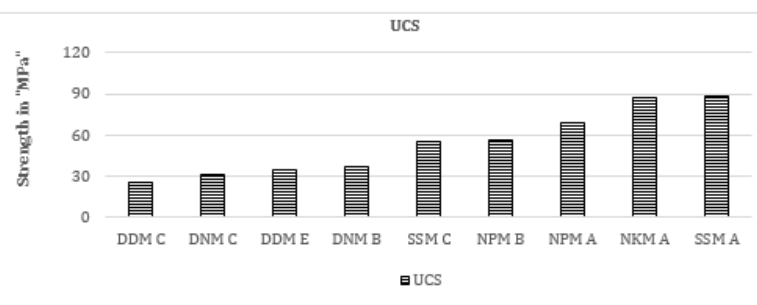

Figure 10: Stress-strain result of UCS test

\subsection{Sonic Pulse Velocity Test}

Sonic Pulse Velocity test is performed to measure the pulse velocity through samples. The pulse velocity test was performed in both dry and saturated conditions. Sonic pulse velocity tests were conducted on 7 samples of sandstone (SSM A, SSM C, DDM E, DDM B, NPM A, DNM B and NKM A) The minimum pulse velocity value in dry condition is $28.4 \mathrm{~km} / \mathrm{Sec}$ and maximum pulse velocity value in dry condition is $55.8 \mathrm{~km} / \mathrm{Sec}$. The minimum pulse velocity value in saturated condition is $26.2 \mathrm{~km} / \mathrm{Sec}$ and maximum pulse velocity value in saturated condition is $49.0 \mathrm{~km} / \mathrm{Sec}$. Sonic Pulse velocity dependent of composition of mineral, porosity, arrangement of grains, water content and cracks presence. Macroscopic feature samples assessing velocity are composed with the usual of the total velocity in the minerals [17] and fluid current within the porous network (water and air), transformed by the intersection of solid and fluid interfaces [17].

Both dry and wet samples are measured. The measuring Obtained results of Sonic Pulse velocity range for wet samples from 26.2 to $49.0 \mathrm{~km} / \mathrm{s}$ and for dry sample the range from 28.4 to $55.8 \mathrm{~km} / \mathrm{Sec}$. By compression we observe that high values are obtained for dry samples that is VP (wet) < VP (dry). With the increase in Sonic Pulse velocity decreases in porosity. The result is shown in Fig 11.

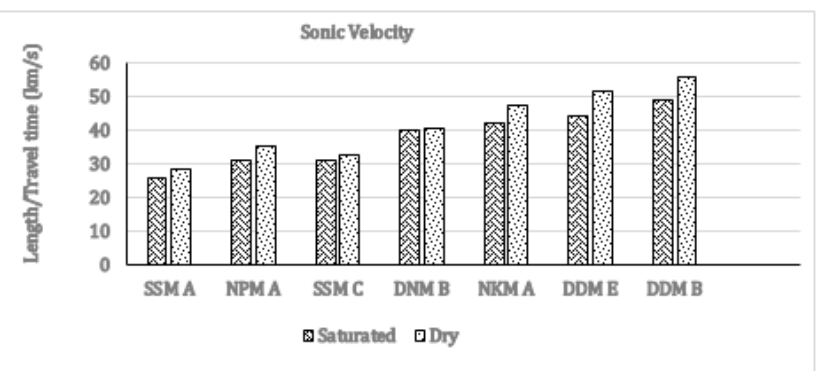

Figure 11: Sonic Pulse Velocity of samples with respect to time

\subsection{Brazilian Test}

It is an indirect method for stretched behavior of brittle material like concrete [18] and rock. The splitting tensile strength depending on the Brazilian test [19]. It can be calculated by using this formula

$\sigma \mathrm{t}=2 \mathrm{P} /(\pi \mathrm{DL})$

Test conduct on 4 samples which were collected during field the result values are Maximum value 5.61 Mpa minimum value $0.76 \mathrm{Mpa}$ and average 
value $2.74 \mathrm{Mpa}$. In this test samples are inclined at different angle from $0^{\circ}$ to $90^{\circ}$ (loading direction). Orientation can be evaluated with respect to loading direction the test is repeated on more samples to get the failure behavior to a specific inclination direction. The average variation of failure strength corresponds rock samples NKM A, SSM A, DDM C and NPM A varies between $0.76 \mathrm{Mpa}, 1.117 \mathrm{Mpa}, 2.32 \mathrm{Mpa}$ and $5.61 \mathrm{Mpa}$ is respectively shown in fig 12. The difference between highest and lowest reading of the failure strength is $4.85 \mathrm{Mpa}$. From previous literature the largest typical samples or rocks failure strength resembles mainly sub-type b rocks samples which differ between the values $15.1 \mathrm{MPa}$ and $11.3 \mathrm{MPa}$, and lowest resembles samples of sub-type a which have values between 14.2 MPa and 5.3Mpa [20]. These tested values are more failure strength than present study tested values. After failure different type of fracture can be observed. That is parallel to the isotropic layers, parallel to loading direction, some are in a curve. The fracture length is used to estimate the failure mode.

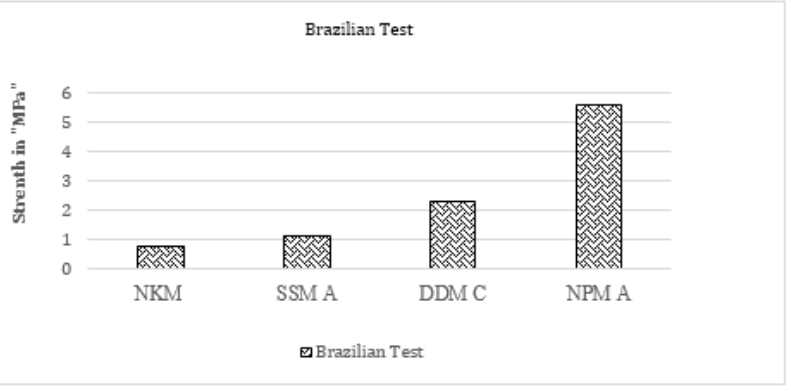

Figure 12: Brazilian test strength values of samples in "Mpa"

\subsection{Point load Strength Test (PLT)}

The PLT test is commonly useable to define the indirectly compressive asset because of its affluence (carefully or gradually) of testing, ease for sampling and potential field application [21] to determine PLS of index rocks [22] for rock slope design.

In PLT testing, rock samplings positioned between two conical platens [23] applying a load through hydraulic jack as result break or fracture the sample in tension [33], extensional planes or rigidity area containing the line of packing [23]. The specimen's external dimensions range in between $30 \mathrm{~mm}$ to $85 \mathrm{~mm}$ with the preferred dimension about $50 \mathrm{~mm}$. Size and shape are axial, block, irregular and determine the water content of each specimen after testing since it can affect the load strength value determine of index rock by using $\left(\mathrm{I}_{\mathrm{s}}\right)=\left(\mathrm{P}^{*} 1000\right) / \mathrm{D}^{2} \mathrm{Mpa}$ and $\mathrm{I}_{\mathrm{s} 50}=$ $\left(\mathrm{P}^{*} 1000\right) /\left(\mathrm{D}_{\mathrm{e}}{ }^{1.5} \sqrt{50}\right) \mathrm{Mpa}$. A test conducted on 4 different samples collected from the project area. Point load test results are Maximum value 3.39 Is (50) in MPa, minimum value 0.84 Is (50) in MPa and average value 1.6 Is (50) in Mpa shows in Fig 13. Load strength index (Is) applied along a single weakness plane at least strength and perpendicular to the direction of least strength for greater strength. The Measurement test result values are greater means greater strength. From Present tested results NPM B have highest strength value and DDM C have lowest strength value.

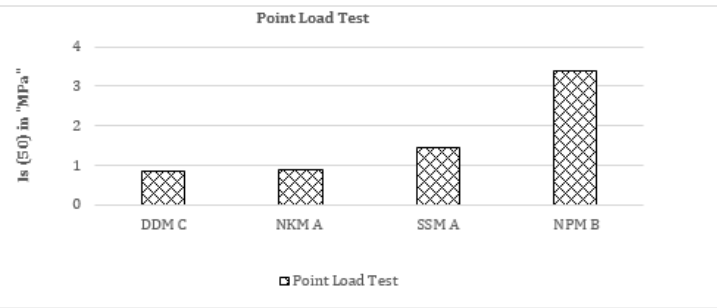

Figure 13: PLT values of samples in Is (50)

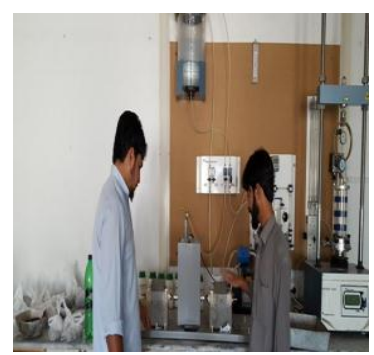

Figure 14: Slake Durability Test

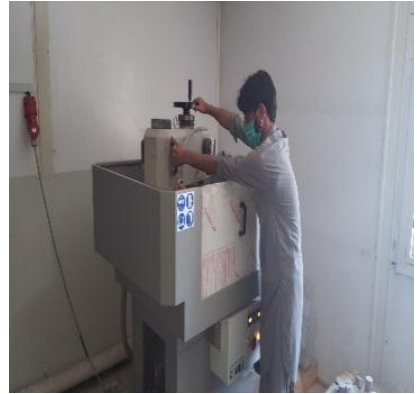

Figure 15: Grinding of Cored Samples

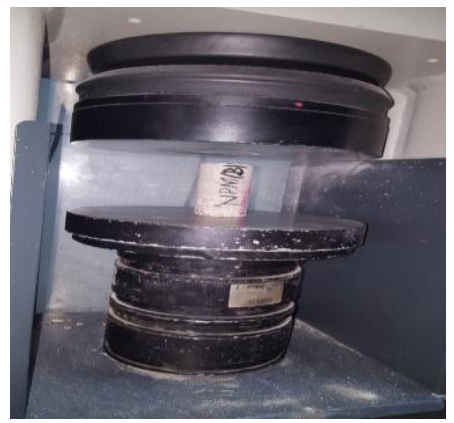

Figure 16: UCS Test

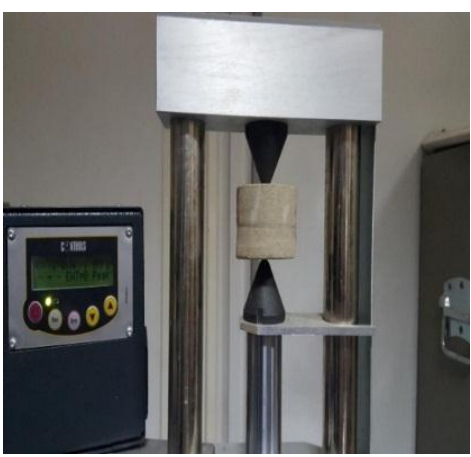

Figure 17: Point Load Test

\section{STATISTICAL ANALYSIS}

\subsection{Relationship of UCS and Sonic Pulse Velocity}

Non-destructive method Sonic Velocity and UCS carried on samples of sandstone to understand or predict the mentioned parameters and Purpose. These methods are based on the empirical relation between strength and predicted parameters and correlate the admixture of sediments sonic pulse velocity and UCS. By assessment to these equivalence with other associated proposed equation outcome have more precise values and correlation coefficient $\left(R^{2}\right)$ [23]. For essentially using the equations are, very modest, most precise and dependable enough to apply for the applicable prediction determinations [23].

Correlated the predictable values beside porosity calculated standards through core samples which were composed from the field and originate to have outstanding level of correlation $(\mathrm{R}=0.94604)$ [24] this value is the strongly correlated value than the previous literature value. Also correlated the predictable porosity value against the immobile and dynamic performance of the basalt and were establish a decent level of correlation $(R=0.77)$ [24]. UCS and Sonic Pulse Velocity (Vp) correlation presented in Figure 17. Relationships depict positive or Negative correlations, linear function exhibited statistically more realistic the results from empirical equations. A linear relation shows between UCS and Sonic Pulse Velocity having a strong correlation. The relation has statically significance. The statistical significance correlation was determined by the standard test where in the computed $t$ value $[t=r *(n-2) 1 \backslash 2 /(1-r 2)]$ was checked against a critical $t$ value. If the $t$ value of computation was more than the critical $t$ value the correlation coefficient was statistically lesser or greater than zero, which means the relationship can be used for the prediction of the dependent variable from the independent variable [25]. The pulse velocity, Vp increases with increasing depth due to densification and the stratification of layered sedimentary rocks. The UCS can be also related to sonic pulse velocity [26]. By regression analysis equation of 
coefficient determination $\left(\mathrm{R}^{2}\right)$ the best appropriate relationships were acquired to be well signified by linear regression [17], it enhanced predictable UCS values concluded a broader variety of Sonic Pulse Velocity values . It is possible with Sonic Pulse velocity range of saturated samples from 26.2 to $49.0 \mathrm{~km} / \mathrm{s}$ and for dry sample the range from 28.4 to 55.8 $\mathrm{km} / \mathrm{s}$. Misleading result produce for high and low values of Sonic Pulse velocity. Therefore, not be used to validate .The lithology is a estimated aspect for the intention of P-wave velocity [17]. In sedimentary rocks Pwave velocity are great for carbonates and at low P-wave velocity of the sandstones [17]. The exponential function offered a enhanced estimate at lower standards of Sonic Pulse Velocity but it overvalued UCS at higher standards. It can be experiential from fig 18 were acquired to be well signified by linear regression correlation between UCS and Sonic Pulse Velocity

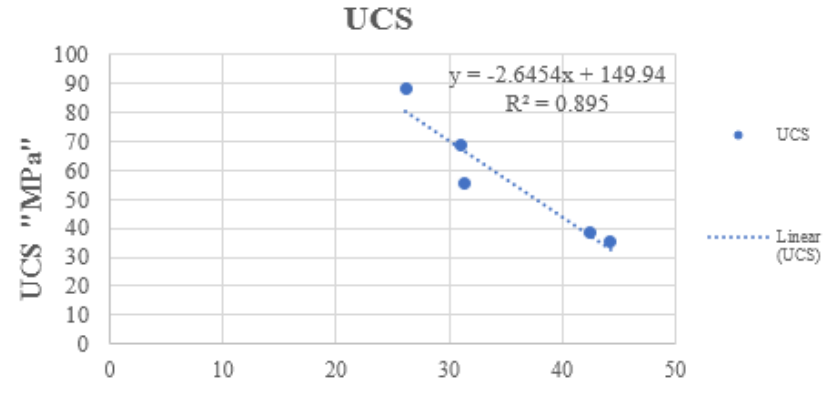

Sonic Pulse Velocity"Km/s"

Figure 18: Relationship of UC Strength vs Sonic Pulse Velocity

\subsection{Relationship of UCS vs PLT}

NX size core samples were used for testing which collected from the project area. The testing was preformed with the help of PLT tester and a universal test performing machine to establish a relevant relationship between the PLT index and UCS [21]. An increasing trend was obtained during the correlation [27]. The correlation coefficients of UCS and Point Load Index were found through statistical regression analysis. Due to the greater coefficient of correlation results power function was the more reliable. Thus, it provided a better estimation of UCS for a wide range of $\mathrm{I}_{\mathrm{s}(50)}$ values.

The determination coefficient $\left(\mathrm{R}^{2}=0.1041\right)$. Relationships depict positive correlations, linear function exhibited statistically and the results of empirical equations $(\mathrm{R}=0.322698)$ shows correlation parameters is no reliable. In addition, the value of $\mathrm{R}$ is close to Zero so there are no relation between USC and Point Load Test. The changeability in the universal compression strength Is(50) relationship may be ascribed to the definite variability in the rock properties due to rocks heterogeneous nature, their other nature characteristic and degree of weathering [28]. The mean and standard unconventionality of test results from PLT and UCS tests were calculated for both the samples [21]. The relation recognized between USC and PLT index is shown graphically in fig 19 . PLT potentially the greatest reliable test for the improvised specimens opportunity strength [23]. The importance of these variation on the act of PLT to frequently produce a smaller posse of distribute, and hence enhance expectation of uniaxial compression strength and the weathering grad [23].

In general, the variability in the PLT-UCS relationship can be attributed to three sources:

1. Inaccuracy in the estimate of the true UCS obtained from UCS tests.

2. Inaccuracy in the estimate of the true PLT obtained from PLT tests.

3. Real differences between the two tests [29].

The power function was the most suitable to the data obtained. Although linear-fit curve was not an ideal one, but it provided better prediction of UCS for lower values of Is (50) [25]. With the increase in depth The UCS is decrease that is inversely proportional which is related to Point Load index behavior. In addition, local correlation method more possibility for error it is due to the inaccuracy variability determination, so the test result can't be acceptable. A good consistency was also apparent between the correlation acquired through Cain and Russel linear and power formula in this study [30].

Among the consequences power function was the supplementary consistent with superior constant of correlation.The equation provided a enhanced assessment of UCS for a inclusive range of Is (50) standards. And the power function was the supreme appropriate with the data acquired

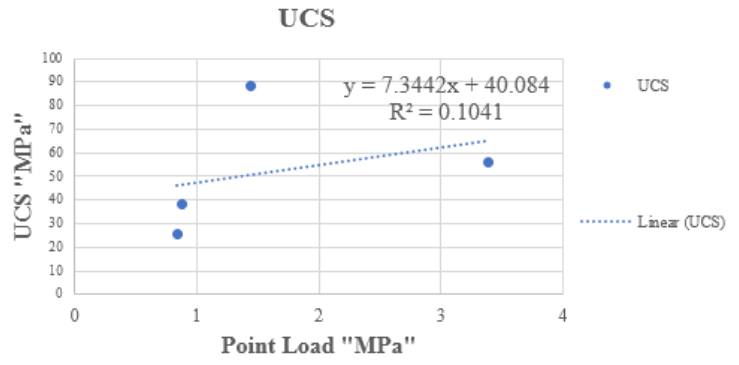

Figure 19: Relationship of UCS vs PLT

\subsection{Relationship of UCS VS Brazilian Test}

Consequently, it can't generalize due to variation of sample from place to place .In Unconfined compressional test (direct strength test) load is applied Under uniaxial loading while Indirect tensile strength test (Brazilian test) load is applied under compression. Axial, diametral and block tests are types of Brazilian test axial type comparable to UCS.

Mainly linear trend was obtained during the correlation of UCS and Brazilian. As increasing in UCS was seen with increasing Brazilian strength values except for sample DDM C. The result of UCS and Brazilian tabulated Fig 20 shows a linear function exhibited statistically and determination coefficient $\left(R^{2}=0.0256\right)$ between UCS and Brazilian. The empirical equations $(\mathrm{R}=0.160002)$ show correlation parameters are no more reliable. Agustawijaya (2007) pointed out that weaker sandstones are low resistive and more penetrating than harder rocks vary in wetness content than rocks and concluded that the texture of the rock, that is the proportion of grain contact, is responsible for decreasing the strength of sandstone [26]. Further, he found that an increase in moisture content tends to decrease the range of elastic nature of sandstone [26]. Test summarizes average results of the samples in the figure 19, the UCS values of the tested rocks were classified according to the strength categories of intact rock by Deere and Miller [31]. As the study samples were placed in between weak and moderately hard rock most rocks have a compressive strength value that is nearly 10 times more than the tensile strength/BT $\left(\sigma_{c} \approx 10 \sigma_{t}\right)$ [31-32]. Current project study, the observed relationships between $\phi$-Brazilian test and $\phi$-Uniaxial compressional test data pairs of determination coefficients. As with very weak positive polynomial relationship between $\phi$ and UCS ( $\mathrm{R}=0.160002)$.

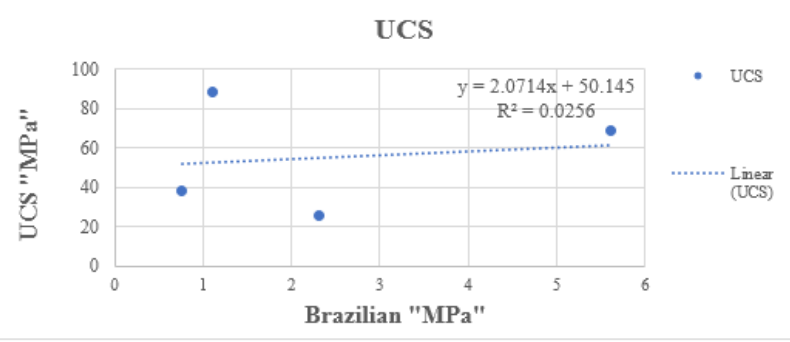

Figure 20: Relationship of UCS vs Brazilian Test

\section{CONCLUSION}

The study area has greater \% of Quartz and Cementing Material. Sandstone is arenite type because samples contain less than $15 \%$ matric. Distribution and orientation in biotite percentage and variability occurrence in Quartz intergranular cracks effect the acceleration and decelerating failure process. Quartz grains are easily deformed by pressure solution. In the current study the slake durability index values of NPM A sample gives an ideal value of strength, it could be claimed that tended to more disintegration due to layer values. The SSM A have maximum strength means low porosity relative to other samples, but overall porosity is high. By compression, highest values are obtained for dry samples that is $V_{\mathrm{P}}$ (saturated) $<\mathrm{V}_{\mathrm{P}}$ (dry). From Present tested results NPM B has highest strength value. Fracture and failure stress affected by layer orientation. More fracture length and diameter correlate with higher strength. The strength depends the inclination angle. If samples placed at low inclination angles than strength is maximum result cause more fractured. The estimated values of dry and wet density were correlated against the geotechnically calculated porosity of rock core samples and fined to have a reliable and valuable correlation. Uniaxial Compressional Strength and Sonic Pulse Velocity shows linear relation. It is statistically more realistic and significance while UCS-Point Load Strength and UCS- 
Brazilian relationships depict positive, linear function exhibited statistically with determination coefficient " $\mathrm{R}$ " is close to Zero so correlation parameters is no reliable and significance.

\section{ACKNOWLEDGMENTS}

The authors gratefully to University of Azad Jammu \& Kashmir and Mr. Sohail Mustafa of the Department of Geology (UAJ\&K) for providing us research guidance, facilities and their laboratories.

Also wish to thankful field group members (Nasir Ahmad, Syed Afaq Maskeen, Nabeel Ahmed, Hassnain Kazmi, Sharafat Ullah, Faisal Majid and Ahmad Farooq) for permission to utilize the relevant data and present this paper.

\section{REFERENCES}

[1] Bila, A., Yasin, M. and Ali, A. 2017. The Geology and Structure Of Neogene Rocks In Dadyal And Adjacent Areas, In The Sub-Himalayas, Azad Jammu And Kashmir, Pakistan. Razi Publishing.

[2] Niaz, A. et al. (no date) Determination of Ground Water Potential in Mirpur AJ\&K Pakistan; using Geoelectric Methods (vertical electrical sounding).

[3] Rafique, M. et al. 2011. Assessment of radiological hazards due to soil and building materials used in Mirpur Azad Kashmir; Pakistan, International Journal of Radiation Research. Novin Medical Radiation Institute, 9(2), 77.

[4] Alam, A. et al. 2015. Tectonic evolution of Kashmir basin in northwest Himalayas, Geomorphology. Elsevier, 239, 114-126.

[5] Barefield, E. and Shakoor, A. 2006. The effect of degree of saturation on the unconfined compressive strength of selected sandstones, in Proceedings of the 10th IAEG International Congress, Nottingham, paper.

[6] Iqbal, O. et al. 2018. Structure and stratigraphy of Rumbli and Panjar areas of Kashmir and Pakistan with the aid of GIS, Journal of the Geological Society of India. Springer, 91(1), 57-66.

[7] Cerveny, P. F. et al. 1988. History of uplift and relief of the Himalaya during the past 18 million years: Evidence from fission-track ages of detrital zircons from sandstones of the Siwalik Group, in New perspectives in basin analysis. Springer, 43-61.

[8] Aadil, N. and Ur Rehman, T. 2013 Stratigraphy and structure of Sarda, Manil, Changpur and Naghal areas, district Kotli, Jammu \& Kashmir, Journal of the Geological Society of India. Springer, 82(6), 639-648.

[9] Mughal, M. S. et al. 2018. Petrography and provenance of the Early Miocene Murree Formation, Himalayan Foreland Basin, Muzaffarabad, Pakistan, Journal of Asian Earth Sciences. Elsevier, 162, 25-40.

[10] Chaudhuri, A., Banerjee, S. and Le Pera, E. 2018. Petrography of Middle Jurassic to Early Cretaceous sandstones in the Kutch Basin, western India: Implications on provenance and basin evolution, Journal of Palaeogeography. Springer, 7(1), 2.

[11] Yasin, M. 2017. Diagenesis of Miocene Sandstone in the District Sudunhoti and Poonch, Azad Jammu and Kashmir, Pakistan, Pakistan Journal of Geology, 1(1), 5-7.

[12] Yasin, M., Ali, S. M. K. and Ishfaque, M. 2017. The Sedimentary Geology, Remote sensing, Geomorphology and Petrology of Miocene to Late Pliocene sediments in District Sudhunhoti and Poonch, Azad Jammu and Kashmir, Pakistan. Zibeline International Publishing.

[13] Yang, Y. and Rosenbaum, M. S. 2002. The artificial neural network as a tool for assessing geotechnical properties, Geotechnical \& Geological Engineering. Springer, 20(2), 149-168.

[14] Gunn, D. A. et al. 2005. Laboratory measurement and correction of thermal properties for application to the rock mass, Geotechnical \& Geological Engineering. Springer, 23(6), 773-791.

[15] Babeesh, C., Lone, A. and Achyuthan, H. 2017. Geochemistry of Manasbal lake sediments, Kashmir: Weathering, provenance and tectonic setting, Journal of the Geological Society of India. Springer, 89(5), 563572.
[16] Martinez-Bofill, J., Corominas, J. and Soler, A. 2004. Behaviour of the weak rock cut slopes and their characterization using the results of the slake durability test, in Engineering Geology for Infrastructure Planning in Europe. Springer, 405-413.

[17] Rahmouni, A. et al. 2013. Prediction of porosity and density of calcarenite rocks from P-wave velocity measurements, International Journal of Geosciences. Scientific Research Publishing, 4(09), 1292.

[18] Khanlari, G., Rafiei, B. and Abdilor, Y. 2015. Evaluation of strength anisotropy and failure modes of laminated sandstones, Arabian Journal of Geosciences. Springer, 8(5), 3089-3102.

[19] Li, D. and Wong, L. N. Y. 2013. The Brazilian disc test for rock mechanics applications: review and new insights, Rock mechanics and rock engineering. Springer, 46(2), 269-287.

[20] Tavallali, A. and Vervoort, A. 2013. Behaviour of layered sandstone under Brazilian test conditions: Layer orientation and shape effects, Journal of Rock Mechanics and Geotechnical Engineering. Elsevier, 5(5), 366-377.

[21] Singh, V. K. and Singh, D. P. 1993. Correlation between point load index and compressive strength for quartzite rocks, Geotechnical and geological Engineering. Springer, 11(4), 269-272.

[22] Palassi, M. and Emami, V. 2014. A new nail penetration test for estimation of rock strength, International Journal of Rock Mechanics and Mining Sciences, (66), 124-127.

[23] Basu, A. and Aydin, A. 2006. Predicting uniaxial compressive strength by point load test: significance of cone penetration, Rock Mechanics and Rock Engineering. Springer, 39(5), 483-490.

[24] Al-Harthi, A. A., Al-Amri, R. M. and Shehata, W. M. 1999. The porosity and engineering properties of vesicular basalt in Saudi Arabia Engineering Geology. Elsevier, 54(3-4), 313-320.

[25] Sheraz, A. M. et al. 2014. Relation Between Uniaxial Compressive Strength, Point Load Index And Sonic Wave Velocity For Dolerite., Pakistan Journal of Science, 66(1)

[26] Jabbar, M. A. 2011. Correlations of point load index and pulse velocity with the uniaxial compressive strength for rocks, Journal of Engineering. Baghdad University, 17(4), 992-1006.

[27] Jasinge, D. et al. 2009. Mechanical properties of reconstituted Australian black coal, Journal of geotechnical and geoenvironmental engineering. American Society of Civil Engineers, 135(7), 980-985.

[28] Zein, A. K. M. and Sandal, M. A. 2018. Estimation of the strength of Nubian sandstone formation from point load test index and other simple parameters, in MATEC Web of Conferences. EDP Sciences, 2024.

[29] Rusnak, J. and Mark, C. 2000. Using the point load test to determine the uniaxial compressive strength of coal measure rock, in Proceedings of the 19th international conference on ground control in mining. Morgantown, WV: West Virginia University, 362-371.

[30] Quane, S. L. and Russell, J. K. 2003. Rock strength as a metric of welding intensity in pyroclastic deposits, European Journal of Mineralogy. E. Schweizerbartsche Verlagsbuchhandlung Science Publishers, 15(5), 855-864.

[31] Karaman, K. et al. 2015. Utilization of the Brazilian test for estimating the uniaxial compressive strength and shear strength parameters, Journa of the Southern African Institute of Mining and Metallurgy. The Southern African Institute of Mining and Metallurgy, 115(3), 185-192.

[32] Ceryan, N. and Can, N. K. 2018. Prediction of The Uniaxial Compressive Strength of Rocks Materials, in Handbook of Research on Trends and Digital Advances in Engineering Geology. IGI Global, 31-96.

[33] Wyllie, D. C. and Mah, C. W.2004. Rock slope engineering 4th Edition. London, Spon Press. 